\title{
"Omdat en zoals het in de Bijbel staat"
}

Gys Bos

Serooskerke Schouw

Nederland

\begin{abstract}
"Because of and exactly as it is written in the Bible"

This article discusses the theological views of $J H$ Gunning jr. (1829-1905), an influential proponent of mineteenth-century Dutch "ethical theology". It focuses on Gunning's lecture "Discipelen des Woords" ("Disciples of the Word"), presented in 1883 at the University of Amsterdam. In the same year a brochure with the same title was published. This article addresses issues such as theology as a scientific enterprise attached to Scripture, value judgements in dialogue with Scripture, the credibility of the Bible as Word of God, Jesus Christ's incarnation, and Jesus Christ's kingship. The article concludes with a reflection on the inadequacies of both liberal and orthodax theology in light of the distinctive characteristics of the Protestant tradition. According to Gunning, the "kingly. work" of God qualifies the Protestant character of the church as absolutely and continually dependent on Jesus Christ as the head of the church.
\end{abstract}

De voorganger der gemeente behoort al wat hij gelooften predikt, eenvoudig daarom en alzo te geloven en te prediken, omdat en zoals het in de Bijbel staat.

(J H Gunning jr, Discipelen des Woords, blz. 5)

\section{INLEIDING}

In september 1883 is de kerkelijke hoogleraar aan de Stedelijke Universiteit van Amsterdam J H Gunning jr zijn lessen begonnen met de toespraak: Discipelen des Woords. Bij de uitgave van deze lezing een paar weken later geeft hij naar zijn gewoonte in een "Voorrede" en in uitgebreide noten een nadere uitleg van zijn bedoelingen, omdat 
hij zich zorgen maakt over de verstaanbaarheid van zijn toespraak. En vervolgens vat hij in bovenstaand citaat de inhoud nog eens kort samen.

Hij benadrukt dat zowel voor de godgeleerdheid als voor de wetenschap deze richtlijn van fundamentele betekenis is. $Z$ ij bewaart enerzijds voor dwaling en geeft anderzijds volle vrijheid aan beide studierichtingen. Dit is immers slechts mogelijk, wanneer men zich volstrekt gebonden weet aan het voorwerp van studie en niet van buiten allerlei invloeden en gedachten laat meespelen.

Wel is onmisbaar voor het verstaan van de diepe en brede betekenis van Gods Woord "de volle gemeenschap met God, die eerst in Jezus Christus aan de mensheid werd geschonken" (Gunning 1883:6). Dat is zoveel als delen in "het geloof der Gemeente" - een typische uitdrukking in het werk van Gunning. In deze relatie wordt de persoonlijkheid van de mens geboren, waarin het persoonlijke en het algemene hand in hand gaan - in tegenstelling met het individu, dat zich terug trekt op zichzelf en daardoor $\mathrm{nu}$ juist de echte vrijheid niet kent. Geloven is niet een stelsel van gedachten aanhangen, maar een persoonlijke betrokkenheid op God die Zich in Christus geopenbaard heeft door de Heilige Geest. De Geest is het die "alles wat de gemeente gelooft en belijdt met het merk van het persoonlijke stempelt" (Gunning 1883:7).

Wie was Gunning en wat was zijn positie in de kerk en de theologie van zijn dagen? J. H. Gunning jr was na zijn studie aan de universiteit te Utrecht predikant geworden in de Nederlandse hervormde kerk. Ruim 20 jaar heeft hij de gemeente in Den -Haag mogen dienen, totdat hij hoogleraar werd in Amsterdam en vanaf 1889 in Leiden. Hij is overleden in 1905 op de leeftijd van 75 jaar.

Hij wordt als één van de vaders van de zogenaamde ethische richting beschouwd - naast D. Chantepie de la Saussaye (gest. 1874). Deze richtings-aanduiding is op zijn minst aanleiding geweest van veel misverstanden, maar door hen die hierbij zouden horen ook volstrekt afgewezen als onjuist. Dat misverstand ligt hierin, dat het woord ethisch hier niet de algemeen aanvaarde betekenis heeft van betrokken op het handelen van de mens. Dan wordt het in verband gebracht met het woord ethiek. Dit begrip is echter afgeleid van een ander Grieks woord, dat betekent: hart, gezindheid, leven. Zij benadrukten daarom steeds weer dat de waarheid ethisch is. 
Nu kan de samenvatting van de voorrede, die zoeven gegeven werd, des te beter verstaan worden. Omdat de waarheid in principe niet zozeer met het verstand en zeker niet uitsluitend met het handelen te maken heeft, maar veelmeer met het hart van de mens en daardoor persoonlijk getekend is, doet het ons wellicht denken aan de existentialistische filosofie van na de tweede wereldoorlog. Toch is er een groot verschil, want terwijl deze filosofie de mens losmaakte uit alle verbanden om hem zo tot de ware vrijheid te willen brengen, heeft iemand als Gunning steeds weer gezegd dat die vrijheid alleen door het geloof gerealiseerd kan worden. En geloof is in de eerste plaats een relatie van persoon tot persoon, van hart tot hart. Later zal deze verhouding gevolgen blijken te hebben voor het denken en het handelen van de mens. Ook zal de godgeleerdheid een belangrijke taak hebben om ons nader in te lichten over deze relatie en zijn brede gevolgen voor het leven van de mens en van heel Gods schepping. Maar alleen de mens, die Christus kent, zal deze taken in beginsel kunnen volbrengen.

Zo hebben we hopelijk een misverstand weggenomen. Over blijft de afwijzing van het begrip ethische richting. Gunning en zijn medestanders beseffen heel goed, dat deze opvatting over geloof in zijn relatie tot weten verstaan zal worden door iedere ware gelovige en daarom kan noch mag zij leiden tot een "ethische" partij of richting. Wel menen zij, dat zij dit principe meer dan anderen betrekken op heel hun positie in kerk en maatschappij inclusief de universiteit. Dat mag wel hun bijzondere plaats accentueren, maar tegelijk erkennen zij nog maar nauwelijks geslaagd zijn in de concretisering van hun visie. Er is dus geen enkele reden zich aan te bieden als partij in de kerk. En anderen mogen hen niet als een aparte richting aankondigen, als zij zichzelf niet tekort willen doen.

Wat deze zienswijze betekent voor predikanten, wil hij graag aan de studenten duidelijk maken. Het heeft met name grote gevolgen voor hun omgaan met de Bijbel. We horen niet van reacties bij de studenten, maar door de uitgave van deze toespraak komen er wel vragen en opmerkingen van buiten. Gunning voelt zich gedwongen verantwoording af te leggen van zijn inzichten en dat doet hij in een brochure die aan het eind van dat jaar verschijnt onder de titel: Omdat en zoals het in de Bijbel staat: Een woord van toelichting. 
Hij had zich overigens al eerder uitgelaten over dit onderwerp naar aanleiding van vragen over en kritiek op gedane uitspraken. Zo had Kuyper in zijn bekende geschrift Confidentie uit 1873 een aantal indringende vragen gesteld aan Gunning. Hierop had hij geantwoord in de brochure De heilige schrift, gods woord.

Enige jaren later leefde de discussie weer op naar aanleiding van de uitgave van een eerste deel van een groot boek Het leven van Jezus, waarin Gunning nogal argeloos schreef over mythen en sagen in de geboortegeschiedenis van de Here Jezus. Er werd fel gereageerd door met name Kuyper en Gunning heeft uitgebreid verantwoording afgelegd van zijn - naar zijn mening - diep gelovig en eerbiedig omgaan met DE HEILIGE SCHRIFT, GODS WOORD in de brochure OVERLEVERING EN WETENSCHAP met betrekking tot de Evangelische Geschiedenis inzonderheid van de eerste levensdagen des Heren.(1879). En tegénover zijn studenten vat hij zijn diepe overtuiging samen in de belijdenis: we kunnen alleen de gemeente dienen, wanneer we geloven en preken omdat en zoals het in de Bijbel staat. In dit artikel willen we proberen te verstaan wat hij daarmee bedoelt.

\section{DISCIPELEN}

Gunning gaat ervan uit dat zijn toehoorders over cen aantal zaken het volledig met hem eens zullen zijn. Hij noemt de volgende zekerheden:

de hele schepping streeft onbewust naar volmaking, naar echt leven. De mens is als de kroon van de schepping zich van dat streven wel bewust. Hij weet ook, dat het doel ligt in de gemeenschap met God. Ons is geopenbaard, dat het ware leven in Christus, het vlees geworden Woord van God, bereikt is. En deze Christus leeft in de gemeente door de Heilige Geest.

Het is de opdracht van de mens om zich dat leven toe te eigenen. Wanneer hij dat niet doet, blijft dat leven als een wet tegenover hem staan. En zoals elke wet zal ook deze niets anders doen dan de dood bevestigen, waarin de zondaar van nature ligt (vgl 2 Cor 3). Wanneer hij echter door het geloof Christus aanvaardt, zal Deze in hem dat nieuwe, ware leven werken. 
Omdat dit leven geschonken wordt in de gebrokenheid van ons door de zonde getekende werkelijkheid wordt het bestaan van de gelovige ook gevuld met verwachting. "De verwachting van de toekomst, de wederkomst van Jezus Christus is niet een betwistbaar zonderling apart leerstuk, maar levensvoorwaarde tot elk waarlijk welgegrond geloof" (Gunning 1883:33).

Het moge nu ook duidelijk zijn, dat geloven is een persoonlijk gericht zijn op het Woord van God, dat de tweede persoon is van de Driežnige God, "die is overgeleverd om onze overtredingen en opgewekt om onze rechtvaardiging" (Rom 4,25). Door deze betrokkenheid op de opgestane Heiland kan het geloof genoemd worden "de inwendige zijde van Gods opstandingswerk"(11).

De verschillende belijdenissen van zoveel kerken over de hele wereld getuigen van dat leven, dat hen door God geschonken is in Christus. Ieder doet dat op een eigen wijze. Benadrukt moet worden, dat bewust gesproken is van getuigen. Er is geen sprake van bewijzen, omdat dat slechts mogelijk is, wanneer de Here Jezus is gekomen in zijn volle heerlijkheid.

De taak van de gemeente bestaat niet alleen uit belijden maar ook uit het oefenen van tucht. $\mathrm{Er}$ is in feite sprake van twee zijden van dezelfde zaak: binden en ontbinden. De Heiland spreekt terecht van de eeuwigheidswaarde van dat werk in de gemeente (Matth 16, 18vv). In haar belijden van de Naam des Heren, betuigt zij haar volstrekte betrokkenheid op Christus. Daardoor zal er zijn "een ontbinden van de macht des doods voor al wat deze belijdenis aanneemt, maar ook een bevestigen van de band des doods voor al wat zich door dat Woord niet wil laten bevrijden" (Gunning 1883:12).

Omdat de volledige doorbraak van het heil in Christus om verschillende redenen (vgl 2 Petrus 3) op zich liet wachten, heeft de Heilige Geest ter bescherming van het geloof der gemeente de schriftelijke neerslag van het Woord van God tot stand gebracht en dat werk afgerond door de vaststelling van de kanon. Deze is niet bedoeld om de afwezige Christus te vervangen, maar veelmeer om Hem die (op zijn bepaalde, voorlopige wijze) nabij is, te belijden en te prediken in zijn volheid van genade en leven. Dit geschiedt door personen die daartoe geroepen zijn. "Niet uit de gemeente, maar uit Christus door de gemeente, komt deze bediening voort" (Gunning 1883:12). 
In haar theologie formuleert de gemeente op stelselmatige wijze het leven, dat zij mag kennen. "Van God geleerd, God lerende, de ere Gods dienende - alle theologie, welke dit niet doet, is ijdel en leugen" (Gunning 1883:13). De ware theologie is uit het eeuwige Woord, dat alle dingen draagt en dat als leven en licht in onze geschiedenis is binnen getreden èn naar het geschreven Woord, dat door de Heilige Geest ons is aangereikt.

De uitspraken van de theologie hebben daardoor een speciaal karakter. Gunning noemt hen in onderscheid met zogenaamde wetenschappelijke gezegden waardeoordelen. "Een waarde-oordeel is een oordeel dat de mens vormt niet met zijn verstand alleen, maar met zijn gehele ongedeelde persoonlijkheid" (Gunning 1883:14). Terwijl de wetenschap een beroep doet op het verstand, dat alle mensen deelachtig is geworden, kan een mens die een waarde-oordeel uitspreekt slechts verstaan worden door iemand die van hetzelfde gevoelen is. Omdat ieder mens een geweten heeft gekregen, is er altijd de mogelijkheid tot geestverwantschap in het algemeen en zelfs tot deze heel bijzondere geestelijke verwantschap, maar zij wordt pas werkelijkheid, wanneer een mens vernieuwd wordt door de Heilige Geest.

De theologie moet zich steeds laten leiden door de Heilige Schrift, omdat zij voor ons het voorbeeld mag zijn, hoe wij met wetenschappelijke uitspraken hebben om te gaan. In haar is alles altijd in verband met het Koninkrijk der hemelen, aldus Gunning. Het zijn godsdienstige waarheden en daarom voor alle tijden waar. Als beginselen kunnen zij dan toegepast worden voor alle vakken van wetenschap. "Wie in de Schrift de wetenschap onmiddellijk liefheeft, onmiddellijk, als uitgesproken stelling, haar wil vinden, zal haar d.i. de wetenschap verliezen, d.i. haar in de Schrift niet aantreffen. Maar wie haar in de Schrift naar haar tijdelijke vorm, als ogenblikkelijk gereedliggende stelling, zal verliezen, die zal haar bewaren in haar eeuwige leven, in haar eeuwige waarheidskern" (Gunning 1883:37).

Maar dat is subjectivisme, dat is bouwen op het meest onzekere fundament dat maar bestaat, zo klinkt het uit de mond van zowel orthodoxe als vrijzinnige toehoorders. De eerste verwijst dan naar Schrift en dogma als houvast en de tweede waagt het liever met het algemeen geldende verstand van ons mensen. Gunning wijst de beschuldiging verontwaardigd af, omdat er geen sprake is van bouwen op menselijke gevoelens, die 
nooit zekerheid kunnen geven. Het geloofsleven bouwt immers op God, die Zich geopenbaard heeft aan de gemeente. God zelf is de hoogste, de énige volle zekerheid. En wanneer Hij onze geest verlicht, ontheft Hij ons juist aan de subjectiviteit. In onze waarde-oordelen openbaren zich Gods gedachten in de onze.

Dat blijft natuurlijk een heel kritisch gebeuren. In de eerste plaats moet de gelovige godgeleerde altijd ervan doordrongen zijn dat Gods Geest in de eerste plaats aan de gemeente geschonken is en dat hij zijn werk alleen goed kan doen, wanneer hij voortdurend zich betrokken weten mag op het geloof der gemeente. Studeerkamergeleerdheid is in deze uit de boze.

In de tweede plaats moet de theoloog voortdurend erop letten, dat hij de van God aangereikte gedachten niet aanvult met toevoegsels van eigen snit, die heel gemakkelijk Gods gedachten kunnen vervormen. Hij zou niet de eerste zijn, die ongemerkt zo bezig is. Heel de geschiedenis van de dogmatiek zou omschreven kunnen worden als een voortdurend zuiveren van de leerstellige vormgeving van het geestelijke leven van gemeente en persoon onder leiding van de Heilige Geest. Het is een geschiedenis van vallen en opstaan.

De mens, die op het gebied van de wetenschap bezig mag zijn, moet zich ook steeds van zijn beperkte opdracht bewust zijn. De overgang van wetenschappelijke uitspraken naar waarde-oordelen is heel gemakkelijk gemaakt. Hij moet zich bij de verschijnselen houden en hun onderlinge verband bestuderen naar de wetten van die verbanden. Wel mag hij geloven, dat in deze verschijnselen nog altijd - ondanks de zonde - de eeuwige werkelijkheid zich manifesteert. Juist vanwege de gebrokenheid van onze werkelijkheid openbaart zich het eeuwige leven op de wijze van het wonder. Het geloof mag dat zien, maar het verstand weet er geen raad mee. Het zal daarom heel terughoudend moeten opereren in de volle bewustheid van de grenzen, die aan hem gesteld zijn. Anderzijds moet het geloof nooit proberen op verstandelijke wijze haar gelijk te halen in een wereld, waar het eeuwige Woord van God nog slechts voorlopig aanwezig is. Helaas is de gemeente zich te weinig bewust geweest van deze beperking met alle nare gevolgen van dien.

Betrokken op het geloof der gemeente kan de christen zich altijd weer laten terug brengen tot Hem, bij Wie het eeuwige leven te vinden is. En de voorganger mag hierbij 
dienstbaar zijn. Voor deze dienstverlening wil Gunning als predikant-hoogleraar voorbereidend werk doen. Hij ziet het als zijn taak "het lied der aanbidding dat in het dogma slaapt" te doen horen. Hij is ervan overtuigd, dat dit lied als een begeerte, als een zucht, als een dikwijls onbewuste behoefte in de mensheid aanwezig is. En hij gelooft, dat "de gehele schepping reeds goed is in de goddelijke blik op haar verkiezing in Christus, haar roeping om verheerlijkt te worden, om eens, na de ondergang van al het verkeerde, goed te zijn" (Gunning 1883:19). Hij verwijst in dit verband met name naar 1 Colosse 1,15vv, waar Paulus schrijft over Christus die langs de weg der verzoening de gemeenschap mogelijk maakt tussen God en zijn schepping. Het is het Woord van God, dat aan deze eeuwige behoefte "de ware uitdrukking, motief, zegel en belofte van vervulling" geeft (Gunning 1883:20). Daarom moeten we discipelen van het Woord zijn. Alleen dan kunnen we geloven en getuigen zoals het behoort, Het Woord is zeker, omdat en zoals het in de Bijbel staat.

\section{OMDAT EN ZOALS}

De reacties op deze toespraak kwamen snel en de kritiek spitste zich toe op het samengaan van de beide woorden: omdat en zoals. In de Kerkelijke Courant van 27 oktober 1883 werd geschreven dat de beide woorden letterlijk genomen hetzelfde zeggen en in feite alleen maar het schriftgezag dubbel onderstrepen. Uit de toespraak blijkt echter dat Gunning dat nu juist niet bedoelde te zeggen. Hij werd daarmee beschuldigd van oneerlijkheid tegenover de gemeente, omdat hij de indruk wekte de onfeilbaarheid van de Schrift te handhaven, terwijl hij die eigenlijk ontkende. Daardoor voelt hij zich gedwongen om zijn opvattingen ter zake nog een keer toe te lichten.

Ter inleiding bepaalt hij nog eens zijn positie door nader te omschrijven wat volgens hem het geloofsleven is. Het wordt bepaald door het volgende:

- Het is een persoonlijke betrokkenheid op Christus.

- Door dat geloof weet een mens van Gods verkiezing tot een levensverbinding met Hem als lid van het lichaam van Christus dat de gemeente is.

- De gemeente is onafscheidelijk verbonden met heel de schepping, omdat de verlossing in Christus kosmische betekenis heeft. 
- De zichtbare wereld waarin wij leven, is slechts voorbereiding op de ware werkelijkheid die in Christus gestalte heeft gekregen en die op Gods tijd tot aan de grenzen van de kosmos werkelijkheid zal worden.

- "In die ware wereld - tot hetwelk alle verlosten en de gehele hogere reine geestenwereld behoren, zijn wij reeds overgebracht, met Christus in de hemel gezet" (vgl Ef. 2, 6).

Dat geeft het christenleven een geweldige spanning en daarom zien wij met groot verlangen uit naar de wederkomst van de Heiland en trachten onszelf en de gemeente daarop voor te bereiden.

Dit alles leert ons de Bijbel, De normale weg, die de gelovige gaat is: van de Bijbel tot Christus en vervolgens weer terug tot de Bijbel. Laten we nooit vergeten dat midden in deze beweging Jezus Christus, het vleesgeworden Woord staat. In Hem kwam God tot ons en alleen op grond van die ontmoeting is er de werkelijkheid van de godsdienst. "Wij hebben geen waarheid in ons ( wel behoefte daaraan), geen waarheid in ons die er het eerst zou zijn en dan door het feit van hetgeen God deed, zou zijn gereinigd, versterkt, verhelderd of hoe men het noeme" (Gunning 1883:7). Toen God tot ons kwam, bracht Hij de waarheid mee. Dat ontdekt de gelovige, als hij luistert naar de Bijbel.

Vervolgens hoort hij nog meer: deze daad van God is geschiedenis, is het hart van de geschiedenis. Er is sprake van een eeuwenlange voorbereiding waarin Israel een centrale plaats heeft gekregen. En na de komst van Christus, die niet alleen vrucht maar ook wortel van Israell is, zien we de gemeente van Christus samengesteld uit alle volken en talen. In de Bijbel vinden de gebeurtenissen alleen naar de zijde van God beschouwd en niet naar hun wereldse wording. Anders gezegd : "alleen als daden, persoonlijke daden Gods, niet als natuurlijke feiten" (Gunning 1883:8).

De éne mens is door verstandelijke vermogens en door opleiding in staat om van deze geschiedenis veel meer te weten dan de ander, waarbij overigens deze kennis ook de nodige smart kan opleveren. Maar ter zake van de "hartelijke" betrokkenheid op deze daden van God is er het ene geloof van de ene grote gemeente, waarin "de kolenbrander en het oude moedertje op dezelfde hoogte staan als de meest ontwikkelde godgeleerde" 
(Gunning 18838:16). Natuurlijk heeft laatstgenoemde de taak om deze gemeenschappelijke ervaringen zo goed mogelijk onder woorden te brengen en te ordenen. Dat blijft een moeilijk te realiseren opdracht, omdat wij deze schat in aarden vaten dragen.

Maar voor de hele gemeente in al haar geledingen is de Schrift een levend geheel, dat zelf zijn gezag meebrengt. "Dezelfde stem, die tot hem kwam toen Gods genade hem bekeerde en die nog steeds in zijn geweten voortklinkt, diezelfde stem, ofschoon met een helderheid welke verre boven zijn ervaring uitgaat, verneemt hij ook in de ons als "Bijbel" overgeleverde heilige Schriften" (Gunning 1883:17). En het is om die reden dat elke oprechte voorganger gelooft en predikt omdat het in de Bijbel staat.

De Bijbel is voor ons niet alleen Gods Woord om zijn inhoud maar ook en niet minder om zijn vorm. Er is sprake van een heilig boek, omdat God het gebruiken wil om Zichzelf bekend te maken door al de woorden en daden die Hij deed in de loop van dé geschiedenis. We hebben echter niet het recht om de Heilige Schrift onfeilbaar te noemen en dat is maar gelukkig ook, want de vele oneffenheden en tegenstrijdigheden op historisch en ander gebied zijn niet te loochenen. De meest geprofileerde rechtzinnige kan dat niet ontkennen. Gunning vindt het niet eerlijk, wanneer men aan een aantal kwesties met een schouderophalen voorbij gaat, omdat het niet belangrijk zou zijn dat aantallen en data niet kloppen. En hij vindt het ronduit onmogelijk om meer belangrijke verschillen door pogingen tot harmonisatie weg te werken. Nee, zo komt men er niet uit.

We moeten bedenken dat onfeilbaarheid een zedelijke eigenschap is, die alleen aan God zelf toekomt. Hij heeft beloofd, dat zijn Geest ons in de waarheid leiden zal. Daarop kunnen wij vertrouwen. En daarom zullen alle zogenaamde zedelijk-godsdienstige uitspraken volstrekt betrouwbaar zijn. Dat zijn de eerder genoemde waardeoordelen. Maar alle mededelingen op historisch, aardrijkskundig en biologisch gebied vallen daar in principe buiten. Daarbij moeten we bedenken, dat de Bijbel zelf nergens van ons eist dat ook deze uitspraken onfeilbaar zijn, "Dit is alleen een gevolgtrekking die men ten onrechte met een overgang tot een ander gebied maakt uit de waarheid dat de Heilige Schrift Gods Woord is" (Gunning 1883:21).

\section{EEN MISVERSTAND}

Voor een aantal lezers was het ineens duidelijk wat Gunning bedoelde. Hij stelde voor om de Bijbel dichterlijk op te vatten. En zij hadden ook al ontdekt, dat dit dè oplossing is 
om uit de problemen te komen. Waar gaat het om? We moeten de tekst van de Bijbel niet letterlijk nemen, maar steeds naar de diepere bedoelingen vragen. Alleen die bedoelingen hebben eeuwigheidswaarde. De aankleding met historische gebeurtenissen, aardrijkskundige feiten of wettische bepalingen is tijdgebonden en daarom voor ons niet meer van waarde. We moeten dus steeds weer dit omhulsel afpellen om de eeuwige waarheid te vinden. Dat is een wijd verbreide manier van omgaan met de Bijbel geworden sinds de moderne wetenschap doorgebroken is.

Voor zulke mensen kan men nog respect hebben, omdat men het niet op wil geven de Bijbel als een eerbiedwaardig boek te beschouwen met grote betekenis voor het leven en sterven van de mens. Zij zagen het als hun roeping deze betekenis te vinden en aan anderen door te geven. Het heeft hen wel pijn gedaan, dat meer rechtzinnige christenen hen voortdurend beschuldigden van heiligschennis, terwijl zij niets anders deden dan " de schat uit het brandende huis te redden". Zo vatten zij immers hun moeilijke werk op. Zij vonden trouwens veel van hun critici niet eerlijk, omdat zij vaak op zekere afstand op dezelfde wijze met de problemen van Gods Woord probeerden klaar te komen.

Gunning wijst zowel de pogingen van deze zogenaamde gematigde orthodoxe als van de moderne bijbelgeleerden af, omdat beiden dezelfde fout maakten. Zij stelden zich namelijk beiden bij hun bijbellezen op het niveau van het natuurlijke weten om vandaar zo mogelijk op te klimmen tot het plan van de geloofskennis. Het verschil tussen beiden was alleen dat de eerstgenoemden veel optimistischer waren over het te verwachten resultaat dan de modernen.

Zoals we eerder zagen, aanvaardt Gunning met dankbaarheid zijn positie in de openbaring van God en alles wat hij doet, moet van daaruit gedaan worden. In navolging van Paulus, die de gemeente verzekert, dat ons burgerschap in de hemel is (Fil 3,20), kan hij niet anders. Dat betekent vreemdelingschap tijdens ons leven op aarde, die immers nog altijd door de zonde getekend is. Wij hebben rekening te houden met de maatschappelijke en wetenschappelijke wetten, die binnen de kring van het aardse bestaan nog steeds gelden. Het is met name de wet van oorzaak en gevolg, waarmee wij te rekenen hebben. Maar juist de gemeente ziet vanuit haar geloofsstandpunt geregeld de hand des Heren oplichten. Hij is kennelijk bezig met zijn schepping te leiden naar de verheerlijking. 
Voor een nadere ontvouwing van zijn gedachten mag ik verwijzen naar hoofdstuk negen van Overlevering en Wetenschap (1879). Voor ons is op dit moment alleen van belang erop te letten, dat we als lid van de gemeente geroepen zijn op onze positie in de openbaring te nemen. Wanneer we vanuit onze aardse werkelijkheid proberen op te klimmen tot God, zullen we met behulp van een diep gewortelde behoefte naar God de grenzen van ons bestaan kunnen overschrijden maar vervolgens verdwalen in de eindeloze d.i. =de onpersoonlijke eeuwigheid.

Wanneer we echter door het geloof met Christus in de hemel zijn gezet, mogen we leven in de wereld van het wonder. Christus is immers de Opgestane en aan Hem is zichtbaar, hoever zijn reddende macht reiken zal. Voor het oog des geloofs zijn de tekenen van dat werk telkens zichtbaar. In de gemeente mag er met de Here God meegedacht, meegezien en meegewerkt worden. En in de leer van "de laatste dingen" geeft zij de verklaring van de zekerheid "dat de wet, die haar geestelijk leven beheerst, eens de wet ook van het zichtbare heelal zal blijken te zijn" (Gunning 1879:157).

\section{IN HET LICHT VAN DE VLEESWORDING}

Voor deze inzichten is de Bijbel van wezenlijk belang, want hoe zouden we het anders te weten komen. Zoals eerder gezegd - de Bijbel brengt ons tot Christus en zijn werk. Maar vervolgens brengt Christus ons weer terug tot de Bijbel en laat zien, dat dit boek ook zelf een gestalte is van dat werk, dat als goddelijke arbeid uniek is. Daarvoor is nodig dat we Gods Woord lezen aan de voeten van de Here Jezus. Anders gezegd: in het licht van de vleeswording. In het leven van Hem is immers openbaar geworden, op welke wijze God met zijn in zonde gevallen schepping reddend omgaat.

Het is kennelijk niet overbodig om te stellen dat er geen kwestie is van met vlees bekleed worden maar van vlees worden. Zowel moderne ais rechtzinnige theologen blijken er moeite te hebben om de vleeswording werkelijk ernstig te nemen. Eerstgenoemden zijn bang, dat de natuur te kort gedaan zal worden, wanneer het Woord werkelijk in haar komen zal. De laatsten menen dat aan de heerlijkheid van het Woord te kort gedaan zal worden, wanneer dat zou moeten plaats vinden.

Alle begrijpelijke overwegingen kunnen niet wegnemen, dat in feite het probleem is dat op de een of andere wijze de onbekeerlijkheid van het hart van de mens een rol 
speelt. Dat is des te gevaarlijker, wanneer dat op verborgen wijze gebeurt. De een heeft het volle vertrouwen in de mogelijkheden van de natuurlijke mens, de ander laat met zo'n overmacht God in onze werkelijkheid komen, dat wij gewone christen-mensen op grote afstand naar de volmaakte Christus en zijn onfeilbare Woord opzien. "Is het echter waar, dat de Schrift een menselijk boek is, in de vorm van onze zwakheid en beperktheid ons de Heilige Geest toeademende, dan treedt dat boek veel nader tot ons, de personen die daarin werken en strijden worden ons veel meer levend en aanschouwelijk, en op de ernst van de bekering wordt veel meer in alle bijzonderheden des levens aangedrongen." (De Heilige Schrift, Gods Woord, blz.50) Dat betekent ook, dat de Bijbel niet slechts ook historische feiten aanreikt, maar veeleer een voluit historisch boek is. Het boek zelf is een gestalte van het ingaan van de Heilige Geest in onze werkelijkheid. "In de taal, in de denkvormen, in de stand der kennis van de oude tijden ging de Heilige Geest, hen (d.i de bijbelschrijvers) bezielende, in" (Omdat en zoals, blz.8).

Laat het duidelijk zijn, dat er geen opzettelijke leugens in de Schrift aanwezig zijn, maar wel zal menselijke beperktheid, ja zelfs dwaling kunnen samengaan met een geleid worden door de Heilige Geest. "Wij die in de Driežnige geloven, wij hebben in de beperktheid des mensen, die door zijn geschapen-zijn reeds gesteld is, een noodzakelijke grens te zien in welke de Heilige Geest zich niet schaamt in te gaan, zo min als de Zoon zich schaamde ons vlees en bloed deelachtig geworden zijnde de dag en de ure van zijn eigen toekomst niet te weten" (Heilige Schrift, blz. 27).

Opnieuw wijst Gunning er hier dus op, dat het juiste zicht op de vleeswording onontbeerlijk is voor het verstaan van het werken van de Heilige Geest. In het mooie boekje Het Kruis des Verlossers heef hij zijn gedachten hierover heel duidelijk verwoord. We luisteren naar een enkele zin om elk misverstand te voorkomen:

De volkomen ontlediging van goddelijke heerlijkheid bracht bij de Zoon Gods hier op aarde ook ontlediging van goddelijke alwetendheid met zich. Anders ware zijn mensheid niet waarachtig geweest en had Hij niet de Voorganger op de weg des geloofs kunnen wezen. Gelijk zijn gehele heiligheid niet was een van de aanvang al voltooide volmaaktheid, maar een voortgang van het gehele leven, voortgang niet van onheiligheid tot heiligheid, maar van onontwikkelde reinheid door aanhoudende strijd tot volkomen gehoorzaamheid, evenzo is 
zijn menselijk weten niet geweest een van de aanvang af voltooide alwetendheid maar een voortgang van het gehele leven: voortgang niet van de dwalingen des waans, des ongeloofs, des halfgeloofs tot de daartegenoverstaande volkomenheid, neen, maar van onontwikkelde eenheid met God, óbk op het gebied des denkens, door aanhoudend toenemende ervaring des levens, tot volkomen macht, óbk des verstands, over hemel en aarde.

(Gunning 1881:4v)

Op de dag van de opstanding heeft de Here Jezus deze macht bereikt en door zijn Geest wil Hij zijn gemeente daarin betrekken. De Schrift is zoals eerder gezegd een gestalte van dit werk, dat pas bij de wederkomst van Christus af zal zijn. Dan zal in de prediking niets te zien en te horen zijn dan Jezus alleen. En dan zal "de gehele theologie met de onweerstaanbare levensmacht der waarheid spreken en aan de radeloze, blinde, stervende mensheid Gods majesteit tonen in haar hoogste kunstwerk: de zelfbewuste mens, de Gemeente der heiligen" (Overlevering, blz.155).

\section{JEZUS CHRISTUS IS KONING}

Om de Schrift te verstaan moeten we haar lezen aan de voeten van Hem, die vlees is geworden en onder ons heeft gewoond. Alleen dan kunnen we verstaan, wat heiliging van onze door zonde en dood getroffen werkelijkheid betekent. Gunning meende hierover nog meer te kunnen zeggen dan wat we zoeven gehoord hebben. Toen wees hij erop dat de Zoon van God ons huidige bestaan heeft aangenomen en dat de Heilige Geest bij de tot stand brenging van de kanon op dezelfde problemen is gestuit. Dat omvattende werk van de Drieěnige God, dat de weg gaat van heiliging tot verheerlijking mag ook bezien worden van de andere kant. De Here God heeft ons niet in het ongewisse gelaten over zijn wijze van werken, al zullen we het niet geheel doorgronden kunnen.

Wanneer Gunning op dit facet van de heiliging ingaat, wijst hij erop dat niet voor niets door heel de Schrift heen de Here God als koning geêerd wordt. En het belangrijkste ambt, wat Christus draagt, is zijn koningschap. Voor ons gevoel is het onderscheid tussen koning en keizer of tsaar bij voorbeeld een kwestie van minder of meer 
macht. Maar gaat het in de Schrift niet om een ander onderscheid? Trouwens wanneer Jezus koning is geworden heeft Hij alle macht in hemel en op aarde ontvangen.

In het lijdensverhaal horen we van het gesprek tussen Pilatus en Jezus, waarbij ook de leden van het sanhedrin betrokken zijn. Pilatus vraagt naar zijn koningschap en daarop geeft de Heiland een positief antwoord. De joden doen een beroep op de rechten van de keizer en dat mag een handigheid zijn om Pilatus te dwingen hun zin te doen, in wezen gaat het om de keuze tussen twee verschillende machthebbers: de koning zoals de Here God die gewild heeft of de keizer bij wie de zondige mens zich kennelijk toch meer thuis voelt. Toch liever Saul dan David? In vele geschriften heeft - vaak terloops Gunning gewezen op het grote onderscheid. De koning naar Gods hart wil de zonde breken en de zondaar maken tot een kind van God door de macht der liefde, die koste wat kost het hart van de mens wil winnen. Wanneer Hij niet in staat blijkt regelrecht de zonde te overwinnen, laat Hij zich overwinnen tot in de dood van de godverlatenheid om zo de mens klein te kunnen krijgen zonder dat deze vernietigd wordt. Alleen langs deze weg kan het geloofsleven, zoals we dat eerder aangeduid hebben, tot stand komen.

De keizer heeft een andere manier van werken. Hij heeft niet zoveel geduld en legt zijn macht zo nodig met geweld op, al worden daardoor ook slachtoffers gemaakt. Het gaat immers om het doel en dat wordt nooit omschreven in termen van persoonlijkheid en gemeenschap.

In de samenleving zien we deze twee manieren van omgaan met mensen overduidelijk, al moeten we wel met de ogen van het geloof leren kijken om de hand van de Koning te zien. Gunning wijst er ons echter op, dat dit onderscheid ook in de wetenschapsbeoefening aan de orde is. Maar vooral ook daar waar je het allerminst verwacht: op het terrein van de godsdienst.

Wanneer het geestelijk leven niet (meer) aanwezig is en men niet het geduld heeft om te wachten op een opleving, worden er dwingend opvattingen en handelwijzen opgelegd. Na het bloeiende geestelijke leven rond Luther en Calvijn met al zijn accentsverschillen zien we het geestelijke leven dalen en dan ontstaan er twistgesprekken en tegenstellingen over allerlei onderwerpen, terwijl men tevoren bereid was vanuit het gezamenlijk beleefde geloof elkaar te aanvaarden ondanks verschillen van mening. 
Om uit deze impasse te komen werden leerstukken opgelegd en duidelijke meningen aangereikt. Het was al genoeg om rechtzinnig te heten en aanvaard te worden als lid van de gemeente, wanneer men bij voorbeeld "de rechtvaardiging van de goddeloze" voor zijn rekening nam zonder dat gevraagd werd of men als zondaar ook de uit genade rechtvaardigende God kende. Terwijl de roomse kerk Christus wilde bewaren voor aantasting van zijn verheven positie door Maria hemelhoog te verheffen, zo heeft de rechtzinnigheid dat gepoogd door de Schrift onfeilbaar te verklaren. "Beide het Romanisme en deze Protestantse orthodoxie dragen het kenmerk te geloven aan de omsluitende vorm meer dan de inhoud en meer voor het behoud, de eer, de partijstelling des geloofs dan voor het geloof zelf geestdrift te hebben" (Heilige Schrift, blz.51). Op zijn manier doet het modernisme hetzelfde door het naturalisme als zekerheid op te leggen. In alle gevallen wordt het gezag bij het verstand gelegd, waardoor de persoonlijke ervaring op de tweede plaats komt als bevestiging of als aanvulling van wat het verstand ons aanreikt.

Deze wijze van doen is des keizers. Het is imperialistisch. "De Koning spreekt niet over zijn gezag. Hij is Koning bij de gratie Gods en laat voelen. De keizer daarentegen, als overweldiger, als parvenu, moet er van spreken om het dreigend te handhaven" (Omdat en Zoals, blz 41. De reden dat dikwijls gekozen wordt als het volk Israel staande tegenover Pilatus, de vertegenwoordiger van de keizer èn koning Jezus: "Wij hebben geen koning, alleen de keizer (Joh 19,15), ligt in het feit, dat de mens tegenover de keizer in feite zichzelf kan blijven." Koning Jezus vraagt de overgave van ons hart. Inmiddels wordt niet gezien, dat de dictatoriale macht van het naturlijke leven wel degelijk ook gestalte krijgt in een persoonlijke macht, die tenslotte op alles beslag zal leggen - niet op de wijze van de liefde maar op de manier van de wet. En deze wet, die van' buiten komt, is dodelijk tenslotte. De keizerlijke figurur, die deze wet hanteert, staat tegenover Christus. Hij is de antichrist.

\section{EEN ECHT PROTESTANTSE KERK NODIG}

Zo staan wij voor een alles beslissende keuze tussen Koning Jezus en de keizer, die meer en meer zich openbaren zal als de antichrist. En de eis om te kiezen komt op alle terreinen des levens op onze weg. Wanneer het gaat om bij voorbeeld politiek of weten- 
schap, weten we ons dikwijls op een tweesprong, hoewel het voor ons gevoel (bijna) onmogelijk is om te kiezen. Ons alledaagse leven eist immers met zoveel klem zijn rechten op. Op het terrein van het kerkelijke leven zien we vaak niet, dat we ook telkens voor deze keuze staan. Haast ongemerkt zijn we terecht gekomen op de weg van de keizer. En het is Gunning geweest, die scherp heeft gezien en tot op vandaag door zijn geschriften ons de gevaren aanwijst en aandringt op de juiste beslissing.

In de voornoemde geschriften ging het eerst over het omgaan met de Bijbel, maar hij maakte ons duidelijk dat we ook de problemen van de moderne bijbelwetenschap alleen de baas kunnen, wanneer we met de Schrift ons wenden tot Jezus Christus. Met een enkel woord hebben we geschetst, dat Hij als koning zijn "almacht der liefde" voor en in ons wil uitoefenen. In het kleinood, dat de titel draagt: Het kruis des Verlossers en dat in verschillende uitgaven verschenen is, schildert Gunning diepgaand de weg en het werk van deze koning.

Wat betekent dat voor de gemeente? $\mathrm{Zij}$ wordt geroepen op een protestantse kerk te zijn. Dat bijvoeglijk naamwoord wil niets zeggen over een groep of partij, die zich tot kerk of gemeente heeft ontwikkeld tegenover andere. Het wil slechts haar volstrekte afhankelijkheid van haar Hoofd Christus tot uitdrukking brengen. Zo is het gebeurd, toen voor het eerst tegenover de Duitse keizer een officieel protest werd kenbaar gemaakt op de rijksdag van Spiers in 1529. Daaraan hebben we deze naam te danken.

Juist het "gereformeerde" kerk-zijn heeft het in zich om op deze wijze zichzelf gestalte te geven. Zoals we zagen, is echterdeze naam niet de garantie, dat werkelijk als gemeente van Christus geleefd wordt. Wanneer het geestelijk leven daalt - met andere woorden: wanneer de levensband met Christus verzwakt, zoekt men al te snel de oplossing in afgeleide zekerheden, terwijl men zich opnieuw ervan bewust zou moeten zijn, dat het leven met Christus gezocht moest worden. Daar het karakter van een echt gereformeerde kerk bepaald wordt door het besef van voorlopigheid met het oog op de heerlijke openbaring van haar Hoofd samen met alle leden, is juist daar de weg terug steeds open. Maar wel zullen de inmiddels ook daar opgeworpen barrières moeten worden opgeruimd. En dat blijft een taak, die pas klaar zal zijn bij de wederkomst van Christus. 
In zo 'n kerk zal Christus als Hoofd heersen en de Heilige Geest dienen. Wanneer we dit onderscheid niet in het $00 \mathrm{~g}$ vatten, gebeurt het heel gemakkelijk, dat de gemeente niet meer ziet, dat de Geest tot Christus brengen wil en daarmee het ware gezag herstelt. Anders krijgt de Heilige Geest snel een geheel eigen betekenis in het leven van de gemeente, die zichtbaar wordt in een meer zogenaamd democratisch bestel, waarin de bekeerden met een beroep op de Geest de dienst uitmaken. Het gevolg is dikwijls verdeeldheid in de vorm van verenigingen naast elkaar of zelfs van partijen tegenover elkaar.

Onze roeping is echter om gestalte te zijn van de ene heilige algemene christelijke kerk, de Catholica, onder het Hoofd Christus. Hij regeert zijn gemeente op zijn eigen wijze. Dat mag zichtbaar worden in personen, die door Hem geroepen zijn om daartoe Hem te dienen. Dat is alleen mogelijk, wanneer zij geloven en prediken, omdat en zoals het in de Bijbel staat.

Dan zal nooit meer vergeten worden, dat "te zeggen dat de Schrift Gods Woord is, niet een orthodoxe theorie is, - maar een oneindig waagstuk, een heerlijke genade Gods in ons. Op deze berghoogte der heilige geestdrift wordt de Heilige Schrift in plaats van overtollig, ons hoe langer hoe onontbeerlijker" (Overlevering, blz.61v).

\section{WE VATTEN IN ENKELE PUNTEN DE CENTRALE GE- DACHTEN SAMEN}

- Het is duidelijk dat Gunning alleen vanuit de gemeenschap met-God over deze dingen spreken wil. Zo denkt hij trouwens over alle loci van de dogmatiek: weglopend uit de houding van gebed en geloof overtreden wij mensen onherroepelijk het tweede gebod door God en zijn werk in te ruilen voor onze beelden die in principe steeds afwijken van Gods werkelijkheid en die trouwens als zodanig ons niet in relatie tot de Here God kunnen brengen. Alleen vanuit de gemeenschap met al Gods kinderen kunnen we de Heilige Schrift als Gods Woord verstaan en waarderen.

- Die gemeenschap is na de zondeval hersteld door Gods Zoon die achter ons aan is gekomen en onder ons wilde wonen. Hij zal echter pas werkelijk kunnen aankomen als Hij komt op de wolken. Dan zal aan alle tegenspraak een einde 
gemaakt worden, maar voordien kunnen wij als gemeente alleen getuigen van de werkelijkheid van Gods komen in het vlees. Alleen met de ogen van het geloof kunnen we Hem volgen op die weg die ons in de Heilige Schrift getekend wordt.

- Heel bijzonder in de visie van Gunning is nu het volgende: dit komen moet gezien worden in het licht van de eeuwige bedoeling van de Drieěnige God met zijn schepping. Met een verwijzing naar de Duitse theoloog Fr Chr Oetinger (17021782) stelt hij herhaaldelijk dat het einde van al Gods wegen de lichamelijkheid is. En de zonde is in principe altijd de weigering om daarin de Here God dienstbaar te zijn.

- Door de zonde is Gods Zoon gedwongen een nieuwe invulling te geven aan zijn komen: het werk der verzoening. Maar het doel blijft tenslotte het wonen van God bij de mensen, hetgeen de verheerlijking van de schepping betekenen zal.

- Volgens Gunning vertelt de Schrift niet alleen van dit komen van God vol belofte, maar is daarvan ook zelf een belangrijke gestalte. Door de Heilige Geest heeft Christus in deze schriftelijke neerslag van Gods Woord een voorbeeld gegeven van de wijze waarop hij koninklijk een plaats bereidt voor zijn wonen onder ons. Daartoe moet al het schepselmatige geheiligd worden tot volstrekte dienstbaarheid. Dat vraagt tijd en maakt ruimte voor de geschiedenis. Daarbij mogen we bedenken dat alleen langs die weg de schepping tot zijn recht komt.

- Bij de uitwerking van deze gedachten moest Gunning zowel de vrijzinnigheid als de orthodoxie van zich weg houden. De vrijzinnigheid is altijd bang dat het natuurlijke te kort komt wanneer de Drieĕnige God werkelijk nabij komt maar miskent daardoor bij de Heilige Schrift de grote betekenis van de heiliging door zijn gestalte slechts te zien als een dichterlijke aankleding van eeuwige waarheden. De orthodoxie wordt altijd gedreven door de angst om God te kort te doen maar miskent op haar beurt evenzeer de betekenis van het natuurlijke voor de inwoning van God.

In feite willen beide richtingen niet zien dat hun opvattingen dikwijls voortkomen uit de weigering in de weg van bekering en zelfverloochening de Drieknige God werkelijk toegang te geven in ons hart en leven. Zelfs de gestalte van de Schrift kan hen hierover het nodige licht verschaffen. 